\title{
University-industry collaboration: constructing a business model lab for student venture creation
}

\author{
Nina Hasche and Gabriel Linton \\ Örebro University School of Business, Örebro, Sweden
}

\begin{abstract}
Purpose - The study aims to examine the development of student venture creation in a co-curricular business model lab initiative with collaboration between students, researchers, technology transfer offices (TTO) and industry. It presents a fresh approach to the study of student venture creation by discussing a unique co-curricular case, its embeddedness in a network and drawing on the concept of tension.

Design/methodology/approach - A qualitative, case-based research design is applied containing data from interviews, observations and active participation.

Findings - The findings point to the inherent difficulties in managing and organizing student venture creation and networks surrounding the student venture creation in a co-curricular setting that can lead to several different types of tensions. Episodes where task-, role-, process-, affective- and value-related tensions arise are identified. Furthermore, the findings highlight that affective-related tension is often an outcome of other types of tensions. Research limitations/implications - Our theoretical implications point to the importance of the context of student venture creation, but not only regarding curricular and co-curricular initiatives; depending on the context, such as if student surrogate entrepreneurship is used, different types of support structure might also be needed to enable student venture creation.

Originality/value - Research on the entrepreneurial university has mainly focused on entrepreneurship education and ventures created by researchers. This study responds to recent calls for research on the venture creation of students. The limited research conducted on student venture creation can be divided between curricular and co-curricular initiatives. Our research points out that many other contextual factors are of importance, such as the origin of ideas, student surrogate entrepreneurship, industry collaboration, team formation and expectations.
\end{abstract}

Keywords Student venture creation, Entrepreneurial university, Student surrogate entrepreneurship, Network, Tension, University-industry collaborations

Paper type Research paper

\section{Introduction}

Entrepreneurship is an important aspect for most universities; it is expected that universities collaborate with industry, create new ventures and educate future entrepreneurs. This can be

(C) Nina Hasche and Gabriel Linton. Published by Emerald Publishing Limited. This article is published under the Creative Commons Attribution (CC BY 4.0) licence. Anyone may reproduce, distribute, translate and create derivative works of this article (for both commercial and non-commercial purposes), subject to full attribution to the original publication and authors. The full terms of this licence may be seen at http://creativecommons.org/licences/by/4.0/legalcode

This paper forms part of a special section "Students creating ventures in higher education - nascent entrepreneurs and entrepreneurship students", guest edited by Lise Aaboen, Roger Sørheim, Dag Håkon Haneberg and Torgeir Aadland.

Nina Hasche and Gabriel Linton are contributed equally to the article.

Funding: This work was supported by the Knowledge Foundation in Sweden and the Faculty for Business, Science, and Technology at Örebro University.

Corrigendum: It has come to the attention of the publisher that the article Hasche, N. and Linton, G. (2021), "University-industry collaboration: constructing a business model lab for student venture creation”, International Journal of Entrepreneurial Behavior \& Research, Vol. 27 No. 5, pp. 1241-1263, listed an incorrect author order. Future citations should reflect this correction. The authors sincerely apologise for this.
Student venture creation with industry

Received 30 September 2020 Revised 21 January 2021 21 April 2021 30 April 2021 Accepted 30 April 2021 
IJEBR

27,5

1242

traced back to how technology and knowledge transfer to the wider society has become more and more important (Goldfarb and Henrekson, 2003), and collaboration with the industry also becomes a more established practice (Etzkowitz and Leydesdorff, 2000). One possible route for universities to become entrepreneurial is through entrepreneurship education and new venture creation, often with the assistance of universities' technology transfer offices (TTO) or knowledge transfer offices (Markman et al., 2005).

Research on entrepreneurship connected to universities has mainly focused on two streams of research: first, researchers starting ventures, and second, entrepreneurship education. Less attention has been directed toward students' venture creation (Boh et al., 2016; Haneberg and Aaboen, 2020). The research on student venture creation can be further divided into two research streams, focusing either on student venture creation within curricula (e.g. Lackéus and Williams Middleton, 2015) or a co-curricular (e.g. Preedy et al., 2020) perspective. In this paper, we use a comprehensive definition of student venture creation by defining it as "venture creation activities of people who are currently studying at a university” (Bergmann et al., 2016).

The university context becomes important for students that start new ventures. It can be argued that the context is more important for student venture creation than for people later in life since students typically lack industry experience and professional networks (Bergmann et al., 2016). Universities that want to become more entrepreneurial through student venture creation have a challenge in how to take action to successfully become entrepreneurial. Students can be valuable resources, but they also face challenges.

Previous research has pinpointed the importance of supportive networks in which student ventures are embedded (Bergmann et al., 2016; Wright et al., 2017; Haneberg and Aaboen, 2020). Support from investors, industry, teachers and TTO create a nurturing environment for student ventures (Wright et al., 2017). Networks and relationships with other actors enable the exchange of knowledge and resources (Alderson, 1957; Bagozzi, 1975a, b; Walter et al., 2006). Existing research highlights the necessity for new ventures to form relationships with other firms (Hasche and Linton, 2018; Kask and Linton, 2013; Street and Cameron, 2007; Walter et al., 2006). Thus, connecting students directly with the latest research, creating an entrepreneurial environment and gaining access to external business partners with experience can help students overcome a lack of industry experiences and professional networks.

However, network embeddedness of a new venture can also result in tensions (Fang et al., 2011; Öberg et al., 2020) as it may result in lock-in as well as lock-out effects, resulting in organizations being trapped in fruitless and uncreative relationships or preventing collaboration with other actors (Gulati et al., 2000). Tensions in university-industry collaborations are often discussed in terms of tensions arising from different institutional logics, that is, an academic logic and a business logic (Steinmo, 2015), where universities and businesses are motivated by different things and are likely to prioritize different goals when collaborating (Ambos et al., 2008). Thus, this paper aims to examine the development of student venture creation in a business model lab initiative with different types of actors involved: students, researchers, TTO and companies. Tension can occur between actors in a network when the motives of individual actors are not realized or when the goals of different actors are difficult to reconcile (Öberg et al., 2020).

The following research questions are addressed:

(1) What types of tensions can be identified between student ventures and a business model lab?

(2) How are tensions handled, and what are the consequences?

We contribute to the student venture creation literature by offering an analysis of tensions when researchers collaborate with the industry to create a laboratory for student venture 
creation. Our contributions point to the importance of the context of student venture creation, but not only regarding curricular and co-curricular initiatives; depending on the context, different types of support might also be needed to enable student venture creation. Our findings also point to the inherent difficulties in managing and organizing student venture creation. The previous literature on student venture creation points to the advantages of networks, which creates many opportunities. Our paper's case illustrates that networks surrounding the student venture creation process can also lead to several different types of tensions. These tensions need to find suitable solutions, and the actors need to learn from the mistakes and reconfigure the network to overcome shortages (Hayter et al., 2017), a learning perspective that can be useful for improvement. Our discussion about student surrogate entrepreneurship can hopefully spark further research interest within student venture creation research. Building on this, we also invite future research to investigate student venture creation and identify other important contextual factors that can impact student venture creation, such as industry collaboration, where the venture's idea comes from team formation.

The paper proceeds as follows: First, we outline the theoretical framework where we discuss entrepreneurial universities, student venture creation as well as opportunities and constraints of being embedded in a network. We also discuss the concept of tension in networks. Thereafter, the research design is explained, and we provide the reader a short introduction to the case's empirical setting. Next, the analysis of different episodes of tensions is presented, and subsequently, the findings are discussed. The paper ends with the conclusions of our study.

\section{Theoretical framework}

\section{Entrepreneurial universities}

The idea of the entrepreneurial university, that is, that universities could be entrepreneurial and part of economic growth and social change, was introduced in the 1980s (Klofsten et al., 2019). The entrepreneurial university can be described as facilitating knowledge transfer, enabling new venture creation and assisting established firms in staying competitive (Etzkowitz et al., 2000; Philpott et al., 2011). Universities have traditionally been seen with a teaching and research mission, but the entrepreneurial university adds the third mission about contributing to economic development.

The triple helix model (Etzkowitz and Leydesdorff, 2000) captures this change with a focus on the collaboration between the three spheres of university-industry-government relations. The triple helix model tries to account for the new configurations that take place in the national innovation system, where the entrepreneurial university, with its knowledge production, becomes an important part of creating value in the innovation system (Cunningham et al., 2018; Hasche et al., 2020).

The entrepreneurial university becomes an important player in the innovation system, and collaboration between industry and government is becoming more important (Etzkowitz et al., 2000). A related way that the university can be entrepreneurial and can transfer knowledge is to create new ventures. The idea that universities should create new ventures is part of the broader idea of technology and knowledge transfer from the universities. This research has mainly focused on researchers becoming entrepreneurs and commercializing their research through academic or university spin-outs (USO) (Jain et al., 2009). These USOs are considered to contribute to the generation of new firms, new jobs and assist in implementing innovative processes (Miranda et al., 2017). Many topics have been covered, including, for example, the entrepreneurial attitude of academics (Abreu et al., 2016), personality traits of academic entrepreneurs (Kolb and Wagner, 2015), gender differences (Goel et al., 2015), size of the personal network (Karlsson and Wigren, 2012) and entrepreneurial passion (Huyghe et al., 2016).

Another way universities can be entrepreneurial is by educating students to become entrepreneurs. As the field of research on entrepreneurship started to form in the 1980s, by the 90 s, entrepreneurship education became increasingly offered at universities 
IJEBR

27,5

1244

(Landström et al., 2012). Research on entrepreneurial education is also seen as one of the most interesting topics for entrepreneurship scholars (Landström and Harirchi, 2019). This might be the reason why university education has sparked much research on topics such as which students intend to enroll in entrepreneurship education (Liñán et al., 2018) if entrepreneurship education affects entrepreneurial intentions (Nabi et al., 2018), entrepreneurship education for engineering students (Aadland and Aaboen, 2020; Barba-Sánchez and Atienza-Sahuquillo, 2018), art students (Thom, 2017) and business students (Herman and Stefanescu, 2017), courses with different types of learning (Robinson et al., 2016) and new methods for teaching entrepreneurship (Linton and Klinton, 2019; Rasmussen and Sørheim, 2006).

\section{Student venture creation}

A topic that has received less attention is students' creation of new ventures (Haneberg and Aaboen, 2020). The literature on student venture creation falls under several different literature streams. As discussed above, some research on student venture creation can be found within the USO stream. Also, some research can be classified to be either a curricular activity or a co-curricular activity. Some universities have courses and programs where students start real ventures within the courses and programs, and this has been studied by some researchers. For example, Lackeus and Williams Middleton (2015) highlight the benefits of closer collaboration between technology transfer and entrepreneurship education and compare different student venture programs. Another stream of research has focused more on student venture creation as a co-curricular activity. For instance, Preedy et al. (2020) investigate student co-curricular activities and how students can learn in different ways through co-curricular activities. Pittaway et al. (2015) research student clubs and highlight how students can gain important practical knowledge from being engaged in student entrepreneurship clubs. In this paper, we explore a unique context of student venture creation based on co-operation between industry and research where a business model lab has been specifically created for students to develop ventures. The business model lab provides direction and support, but the students come up with the ideas, develop the ideas and are the driving force of the ventures.

The life of a student in a university context can play an important role in starting a venture. However, as Shirokova et al. (2017) argue, it is not only about formal curricular and co-curricular activities; it is also about how the wider context at the university can influence the student's entrepreneurial mindset. For example, the possibility of networking, sharing knowledge and the creativity found in a university setting can be important enablers of student venture creation. Students can also play an important role in academic spin-off ventures, as Hayter $e t$ al. (2017) explore. They study graduate students and find that the students are important in the commercialization process and, interestingly, discover that conflicts easily arise over roles, ownership and intellectual properties. Looking more at the support around student venture creation, Wright et al. (2017) suggest a framework of an ecosystem to enable student venture creation. Their proposed framework includes support actors, investors, the university environment, external context and the development of these over time. Also investigating the support around student venture creation, Haneberg and Aaboen (2020) suggest that support for students that focus on technology-based ventures should be need-driven and informal, rather than structured, formal and prescribed by the university. These researchers also pinpoint that multiple university and external actors are vital for the student venture creation process. A good summary of this section would be that previous research on student venture creation highlights the importance of networks and support, the importance of students in venture creation and that conflicts and tension can arise between the actors.

\section{Embeddedness in networks - opportunities and constraints}

Based on the above previous research, it becomes apparent that networks become an important dynamic for student ventures (Wright et al., 2017). Being embedded in a network 
might provide opportunities and can also result in tensions and constraints (see, e.g. Gulati et al., 2000; Fang et al., 2011; Öberg et al., 2020). These networks can assist in, for example, sharing knowledge, expertise, experience, resources and support. In particular, network embeddedness can be a source of opportunity as it potentially provides an organization with access to information, resources, technologies and markets. It allows participating organizations to achieve objectives and create value, such as developing innovations, enabling learning, improving knowledge and competencies and sharing risks (see, e.g. Gulati et al., 2000; Hughes et al., 2007; Nosella and Petroni, 2007).

Previous research has shown that the motives for participating in networks may vary between actors (Corsaro and Snehota, 2011; Gulati et al., 2000) since the motives for engagement often relate to the overall aims of the organizations involved (Oberg and Shih, 2014). For student ventures, this could include how all actors have individually formulated expectations regarding the outcome of such a network to make the individual actors "better off" (Fyrberg Yngfalk, 2011). Previous research has shown that university and industry actors often have different goals and conflicting interests, different working practices and approaches to solve problems and different time horizons, making these university -industry collaborations challenging (Ambos et al., 2008; Meyer et al., 2011; Steinmo, 2015). When the motives of individual actors in the network are not realized or when different actor's motives are incongruous, tension can occur between actors in a network (Öberg et al., 2020; Fang et al., 2011). Tensions can occur between the participating actors when the expected outcome is not realized by one or all actors (Cunningham et al., 2018; Meyer et al., 2011; Popa et al., 2020). Fang et al. (2011, p. 774) define tension as "two co-existing contradictory forces with conflicting goals." These forces can break up relationships and are often the primary causes of aggravation within collaborations. The conflicting notion of tension describes how collaborating actors do not share viewpoints or intentions (Öberg et al., 2020); that is, an actor may perceive a tension between the organization's goals and the goal of the cooperation. Tensions in university-industry collaboration are often rooted in different understandings of each other's working practices, uncertainty and opportunistic behavior, which are found to be eased through collaborative experiences, interaction and trust, as developed over time by the actors involved in the collaboration (Hasche et al., 2020). Most research on tension has been studied on a relational level of analysis, where few studies move beyond dyadic tension (see, e.g. Öberg et al., 2020). In this paper, we discuss tensions in a network consisting of university as well as industry actors, where tensions may be present between two actors within the network, between two actors vis-à-vis the third one, among groups of actors or among all parties involved. On a network level, Mele (2011) identifies five different types of tensions in a network collaboration, that is, task-related, process-related, role-related, affective and values-related tensions. Task-related tensions are related to cognitive components such as, for example, incompatible ideas or opinions about tasks. Processrelated tensions include differing opinions about how tasks should be carried out, for example, how to do something. Role-related tensions involve actors having different opinions about the degree and type of obligations, for example, who should do something and with which responsibility. Affective-related tensions include emotions such as annoyance, frustration and irritation, while value-related tensions involve incompatible value systems.

Based on the above discussion, in this paper, we will analyze a specific business model lab initiative that is simultaneously a university-industry collaboration and student venture creation. The university -industry collaboration clearly sets the stage and gives direction for the students who come up with ideas and are the driving force. However, the initiative is not a circular activity and would not fit in with more traditional co-curricular activities. The students are given not only a platform and some general directions but also the important network of both industry specialists and business researchers. As a theoretical starting point, we were interested in student venture creation and the surrounding network. In the iteration 
IJEBR

27,5

processes between theory and empirical data, we found that tension was an important concept to investigate further; therefore, we added a theory around tensions in networks and also different types of tensions.

\section{Methodology}

In this paper, a qualitative case study (Eisenhardt and Graebner, 2007; Siggelkow, 2007) was considered to be appropriate for examining the development of student venture creation in a business model lab initiative with different types of actors involved. As suggested by Eisenhardt (1989), the case study is an appropriate approach to develop new understandings about a phenomenon where little is known. Scholars interested in networks and relationships between actors frequently use case studies (Dubois and Gadde, 2002) to elaborate an in-depth understanding of the phenomenon (Eisenhardt, 1989) and to expose the complexity embedded in the context (Eisenhardt and Graebner, 2007).

Based on the framing and aim of the paper, it is made clear that the context is very important for student venture creation. Dubois and Gadde (2002, p. 554) argue that "learning from a particular case (conditioned by the environmental context) should be considered a strength rather than a weakness. The interaction between a phenomenon and its context is best understood through in-depth case studies." In this case, the university-industry collaboration clearly sets the stage and gives direction for the students, but the students come up with the ideas, develop the ideas and are the driving force of the ventures. Thus, based on the phenomenon under study and the unique context, this paper is based on a single-case study, where the case is composed of actors from academia as well as the industry. It includes seven different actors (including the student venture), three from academia and four from industry (see Table 1). The three actors from academia are the students engaged in student ventures in

\begin{tabular}{|c|c|c|}
\hline Actor name & $\begin{array}{l}\text { Type of } \\
\text { actor }\end{array}$ & Type of activities \\
\hline $\begin{array}{l}\text { Business model lab (including } \\
\text { student ventures) }\end{array}$ & Academia & $\begin{array}{l}\text { Test bed to create new business models for commercialization. } \\
\text { Consists of different student ventures. Resident at the } \\
\text { university in municipality delta }\end{array}$ \\
\hline Research group & Academia & $\begin{array}{l}\text { Researching the changing electric utility industry and the } \\
\text { development of new business models. Resident at the } \\
\text { university in municipality delta }\end{array}$ \\
\hline TTO & Academia & $\begin{array}{l}\text { Utilize and commercialize ideas and innovations derived from } \\
\text { research and education at the university. Resident at the } \\
\text { university in municipality delta }\end{array}$ \\
\hline Northland energy & Industry & $\begin{array}{l}\text { National electric utility and electricity trader. Resident in } \\
\text { municipality Alfa in the middle part of Sweden with an office } \\
\text { in municipality delta }\end{array}$ \\
\hline Municipal power & Industry & $\begin{array}{l}\text { Local electric utility specialized in providing electricity and } \\
\text { district heating. Resident in municipality beta in the middle } \\
\text { part of Sweden. Operates solely at a local market in } \\
\text { municipality beta with very loval customers }\end{array}$ \\
\hline City utilities & Industry & $\begin{array}{l}\text { Local multi-utility of heat, electricity, water and sewer services } \\
\text { and broadband infrastructure. Resident in municipality } \\
\text { gamma in the middle part of Sweden. Operates solely at a local } \\
\text { market in municipality gamma with very loyal customers }\end{array}$ \\
\hline Sustainable development & Industry & $\begin{array}{l}\text { Development company with the aim of being a catalyst for } \\
\text { sustainable development in municipality delta through } \\
\text { collaborations with other actors in the region (i.e., actors in } \\
\text { municipality beta and gamma) }\end{array}$ \\
\hline
\end{tabular}

Table 1.

Description of actors 
the business model lab, a group of researchers from the business school and a TTO that works to utilize and commercialize ideas and innovations derived from research and education at the university. All industrial actors are companies operating within the electric utility industry in Sweden. In line with Eisenhardt's $(1989,1991)$ argumentation, the seven different actors composing the single case are viewed as "mini-cases." As tensions in this paper represent contradictory viewpoints or intentions, the focus is on how actors perceive matters in different ways, where all seven "mini-cases" are necessary parts of the case.

The case was purposely selected from a larger empirical investigation (cf. Eisenhardt and Graebner, 2007) performed as part of an ongoing research project. First, a unique situation of studying the creation of a student venture and the embeddedness of the same at a very early stage was possible, which made the case special. Often studies of venture creation cannot follow the venture creation process from the start. Research usually identifies new ventures and then uses a retrospective perspective to gain an understanding of the early creation stages. Second, the case offered the possibility to study the development of the student venture as well as the evolvement of the relationships over time. Third, exclusive access to all actors in the network was offered.

\section{Data collection}

Case studies often rely on multiple sources of support (Eisenhardt, 1989; Eisenhardt and Graebner, 2007). Different data collection methods were used to get a rich understanding of the case from multiple perspectives. Researchers interested in networks and relationships often aim to capture the contents of interactions, relationships and networks in thick, rich descriptions (Dubois and Gadde, 2002). A mix of face-to-face interviews and observations (roundtable discussions, student venture board meetings and workshops) were performed between September 2017 and December 2020 (see Tables 2 and 3). The collected mix of data was complementary and gave us a better understanding of the development of student venture creation in a business model lab initiative with different types of actors involved.

\begin{tabular}{|c|c|c|c|c|c|}
\hline Organizations & Position in organizations & & $\begin{array}{c}\text { No of } \\
\text { interviews }\end{array}$ & Duration(s) & Years \\
\hline Northland energy & Head of partner relations & & 1 & $60 \mathrm{~min}$ & 2019 \\
\hline Northland energy & Head of new businesses & Mentor & 3 & $\begin{array}{l}102 \mathrm{~min}, 20 \mathrm{~min} \\
\text { and } 26 \mathrm{~min}\end{array}$ & $\begin{array}{l}2018,2020 \\
\text { and } 2020\end{array}$ \\
\hline Northland energy & R\&D manager & Mentor & 2 & $\begin{array}{l}78 \mathrm{~min} \text { and } \\
20 \mathrm{~min}\end{array}$ & $\begin{array}{l}2018 \text { and } \\
2020\end{array}$ \\
\hline Northland energy & Head of consumer relations & & 1 & $70 \mathrm{~min}$ & 2018 \\
\hline Northland energy & Department manager & Board & 1 & $75 \min$ & 2018 \\
\hline City utilities & $\mathrm{CEO}$ & Board & 1 & $46 \min$ & 2018 \\
\hline City utilities & Deputy CEO & Mentor & 2 & $33 \mathrm{~min}$ & 2017,2020 \\
\hline Municipal power & CEO & Board & 3 & 54,28 and $21 \mathrm{~min}$ & $\begin{array}{l}2017,2018, \\
2019\end{array}$ \\
\hline Municipal power & Communication manager & Mentor & 1 & $20 \mathrm{~min}$ & 2020 \\
\hline $\begin{array}{l}\text { Sustainable } \\
\text { development }\end{array}$ & CEO & Board & 1 & $67 \min$ & 2018 \\
\hline Student venture & Student 1 & & 1 & $42 \mathrm{~min}$ & 2020 \\
\hline Student venture & Student 2 & & 1 & $55 \mathrm{~min}$ & 2020 \\
\hline Student venture & Student 3 & & 1 & $50 \mathrm{~min}$ & 2020 \\
\hline Student venture & $\begin{array}{l}\text { Four students participating } \\
\text { in a group interview }\end{array}$ & & 1 & $45 \mathrm{~min}$ & 2020 \\
\hline TTO & Business developer & Board & 1 & $45 \min$ & 2020 \\
\hline
\end{tabular}

Table 2. Interviews 


\begin{tabular}{|c|c|c|c|}
\hline \multirow{3}{*}{$\begin{array}{l}\text { IJEBR } \\
27,5\end{array}$} & Observations & Amount & Participants \\
\hline & Roundtable discussions & $\begin{array}{l}9 \text { (average } \\
90-120 \mathrm{~min})\end{array}$ & Representatives from four companies and the research group \\
\hline & $\begin{array}{l}\text { Board meetings } \\
\text { (student ventures) }\end{array}$ & $\begin{array}{l}6 \text { (average } \\
90 \text { min) }\end{array}$ & $\begin{array}{l}\text { Representatives from four companies, the research group, } \\
\text { representatives from TTO and sometimes students from } \\
\text { student ventures }\end{array}$ \\
\hline 1248 & Project workshops & 2 full days (16 h) & $\begin{array}{l}\text { Representatives from four companies, the research group, } \\
\text { representatives from TTO and students from student } \\
\text { ventures }\end{array}$ \\
\hline $\begin{array}{l}\text { Table } 3 \text {. } \\
\text { Type of observations }\end{array}$ & $\begin{array}{l}\text { Workshops with } \\
\text { students }\end{array}$ & $\begin{array}{l}7 \text { (average } \\
60-180 \mathrm{~min})\end{array}$ & $\begin{array}{l}\text { The research group, mentors and students from student } \\
\text { ventures }\end{array}$ \\
\hline
\end{tabular}

Interviews. 21 face-to-face interviews have been conducted in total, representing interviews with four companies and the students representing the student ventures and the TTO. Some respondents were interviewed multiple times, and others were interviewed once. We have also performed one group interview with four participating students. Two separate interview guides were prepared in advance, one for business representatives and TTO and one for students. The interview guides have a clear anchoring in the literature discussed. The questions applied an open-ended question approach to ensure the interviewees could speak freely about each theme. The interviewees representing the companies had qualified knowledge on the overall, strategic, market and operational parts of the businesses, where the questions covered areas such as industry change, market trends, offerings, current business models, transformations processes, ongoing collaboration projects, innovation processes, problems and constraints related to being embedded in a network, expectations and progress over time. During some recurring interviews, the interviewees were also asked to reflect upon different episodes during different meetings.

The questions asked to students dealt with the students' backgrounds and previous experience from starting ventures, a collaboration between students, collaboration with mentors, innovation processes, the relationship between student venture and other actors in the innovation net, problems and constraints related to being embedded in a network, expectations and progress over time. The students were also asked to reflect upon different episodes that occurred during different meetings, for example, board meetings where students presented ideas and workshops where students interacted with mentors. All interviews lasted on average around 60-90 min. During most of the interviews, two researchers were present. All interviews (except a few) were recorded using a digital voice recorder and transcribed verbatim.

Observations. Two types of observations were conducted, active participation and observation (Jorgensen, 2015). One of the authors had an inside view and operational assignment from being appointed the CEO in the business model lab (the reasons for this are discussed in the empirical section of the paper). Jorgensen (2015) points out that the active part of this method is what differentiates it from other forms of observation. Active participation is closely related to ethnographic methods and field research and has recently gained legitimacy (Musante and DeWalt, 2010). These types of approaches have been applied to study entrepreneurial networks and new product offerings (see, e.g. Marion et al., 2015; Power et al., 2014) and have been argued to have the potential for researching emergence in entrepreneurship (Johnstone, 2007). The active participative researcher was operative in the venture by participating in, for example, workshops and board meetings. The other researcher had an outside view and has not been operational at all in the business model lab but rather as a silent observer at different types of meetings. Detailed field notes were made 
on all occasions, and when achievable, recordings were made. During meetings, the author that participated as a silent observer also wrote down reflective notes, such as when voice modes or body language changed or when the atmosphere in the room changed in a positive or negative way. Hence, both authors have been present in meetings. They, however, had different roles. This tactic is described by Eisenhardt (1989) as advantageous, where she argues that such a tactic allows the case to be viewed from different perspectives by the researchers involved. It should also be noted that both authors of this paper are part of the research group situated at the business school.

Secondary data. Secondary data has also been collected to improve the understanding of contextual factors and changes in the surrounding ecosystem. In line with this, we collected and studied documents such as annual reports, press releases, press articles and reports from different authorities and interest groups. Hence, the secondary data included both company internal material as well as official material. All data have been accessible for all the researchers involved.

\section{Data analysis}

The process of analyzing the data has been an iterative process between the theory and empirical data. Dubois and Gadde (2002) argue that such an approach of constantly going back and forth between the theory and empirical observations over time expands the researcher's understanding of both the theory and the phenomenon under study. As a theoretical starting point, we were interested in student venture creation and the surrounding network. Thus, the preliminary analytical framework consisted of expressed "preconceptions" (Dubois and Gadde, 2002, p. 555). An iterative approach was adopted to handle the large amount of empirical data, where interview transcripts, detailed field notes and supporting notes were read and re-read several times to allow key recurrent topics to emerge (Miles and Huberman, 1994). As suggested by Eisenhardt (1991), a single-case study consisting of "mini-cases" may follow the same analytical steps as a multiple-case study, that is, within-case analysis and cross-case analysis. During the analysis process, we were inspired by the analytical steps suggested by Eisenhardt (1989), where we, as a first step of the analytical process, put together seven "mini-case descriptions" of each actor and their relationships based on interview transcripts and detailed field notes made during observations. Our initial case descriptions allowed for the construction of a timeline of developing the business model lab and creating the student ventures. The initial case descriptions were then taken as a starting point for discussion and further analysis. The fact that the authors had different roles during the data collection process became valuable when analyzing the data. Since both authors had been present in all meetings, although they had different roles, and the experiences of the different meetings were discussed afterward, it gave a balanced and more nuanced representation of different episodes. As a second step, the "mini-cases" were analyzed as cross-cases (cf. Eisenhardt (1989), where we searched for similarities and dissimilarities. During this phase, tensions between actors became more than a word used in our discussions, and it emerged as a key concept in our understanding of the development of the business model lab for student venture creation. The concept of tension in relationships and networks was added to the theoretical discussion in this paper. Thus, as described by Dubois and Gadde (2002), the theoretical framework was developed over time based on what was discovered through empirical fieldwork as well as analysis and interpretation. The parts of the collected data with relevance to the present paper were coded and related to the various points of the analysis. In the third step, the initial case descriptions were rewritten into a single-case description based on the multiple views derived from the "mini-cases" to better reflect episodes of tension between the actors during the development. The analysis was performed in an exploratory manner, using the case description and, to some extent, insights that we had gained from other research. In the fourth step, the episodes 
IJEBR

27,5

of tension identified were discussed and compared with previous literature to ensure theoretical anchorage and contributions (Eisenhardt, 1989). With tensions becoming central, we identified several types of tensions and reanalyzed the episodes based on types of tensions. The analytical process was not linear; rather, the theoretical framework and the case description have developed through a number of iterations (Dubois and Gadde, 2002). Thus, our analytical process may not have been as linear as discussed by Eisenhardt (1989) but rather non-linear due to the iterations between the theory and empirical data as described by Dubois and Gadde (2014). However, as argued by Dubois and Gadde (2014), there is an overlap between the two approaches when it comes to the analytical process of analyzing cases. Findings were synthesized from previous research to ensure this paper's theoretical contribution and make the findings more precise. The results of this analysis are presented in the upcoming section.

\section{Reflections on the methodology}

As discussed previously, the value of the research design lies in its capacity to provide insights, rich details and thick descriptions. However, we recognize that the research design has limitations. The empirical part of this paper is based on a single-case study. The research design employed prevents generalizability. While it captures multiple collaborations, the empirical scope of the study is limited. We study one case with many actors involved in a particular context under special conditions, where one of the authors has been deeply involved in what is being studied. We realize that active participation can provide reactive effects where the researcher's participation affects how people talk and behave, but active participations' ability to collect rich data and deep understanding is still valuable (Jorgensen, 2015). Our effort to include both active and non-active participation is one way to add reflexibility (Johnstone, 2007). The conducted interviews also add balance and a variety of different types of data. In the methodology section of this paper, we have described our attempts to constantly compare statements from different actors and across different types of data to get a nuanced understanding of the phenomenon under study.

\section{A business model lab initiative}

The work of establishing and launching a business model lab for student venture creation (see Figure 1) started in February 2018. The lab would be a context where students could develop new venture ideas and test new types of business models in a real-life setting within the electric utility industry. The research group was going to study the new ventures that the students created in the business model lab as well as the development of the lab itself. The goal was to develop business models partly based on the research conducted in the field of the electric utility industry.

The four companies engaged in the business model lab with the expectation to learn new things from researchers and students that could be of use in their own businesses over time. The companies were under pressure to change their business models in an industry that was on the verge of being disrupted and saw the engagement as a way of learning about new business models and incorporating them into their own businesses. Another goal of the companies was to learn about students and their preferences as future electric utility customers. The companies, more or less, saw the business model lab as their investment in research and development (R\&D) and product development and valued being near any interesting ventures that would develop in the business lab and also were able to take a stake in such a venture.

The business model lab was set up so that the TTO would own all the shares of the lab but could sell the shares later on if any of the companies wanted to own part of the incorporation. The TTO is a central function of the university, while the research group belongs to the business school of the university, with the two entities belonging to different parts of the 

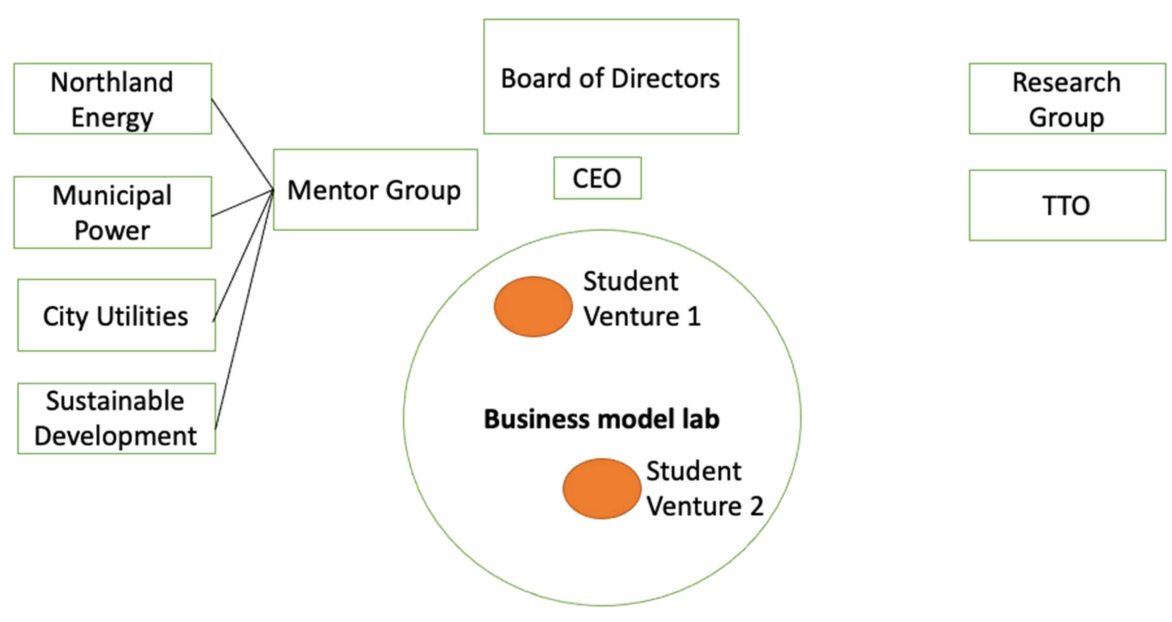

\section{Student venture creation with industry}

1251

university, with only limited joint projects. The TTO required that the CEO and the board chairman would be researchers from the research group since the researchers had employment at the university. The TTO also wanted one of their business developers to be part of the board. In addition, it was also decided that Northland Energy, Municipal Power, City Utilities and Sustainable Development could have one place each at the board. Three of the companies decided to put their CEO on the board, while Northland Energy decided to put a high-level manager in place. In addition, two researchers from the research group and one representative from the TTO formed the board together with the business representatives. Each company also agreed to assign a more operative-level mentor to the project. These mentors would assist the students in a more operational way and in the week-to-week operations with industry insights and other more practical perspectives. The students would present their ideas to the board and report on their progress, but the CEO would help manage the operations and also take care of administrative tasks.

To start the venture creation, students were essential. One issue was how to get students interested in starting ventures within the electric utility industry. It was decided that students would be recruited to the business model lab by highlighting the opportunity of all resources and help available, networking opportunities, unique resume builder and a minor monetary compensation (5000 SEK, which is about equal to 500 euros, per term).

Once students were recruited, teams of students would be formed, preferably containing students with different backgrounds and programs of study. Students were informed about the opportunity in some classes and through social media and flyers on campus. Students applied to become a part of a student venture team and were interviewed by the CEO and the chairman of the board.

In December 2019, the first students were recruited to the business model lab. The first student venture started its operations in January 2020, and this group of students continued until June 2020. The students gave up on their idea because it became too complex, and two of the three original students were done with their studies and moved on. The next student venture started in August 2020 and continued to be in operation when the reporting on this research took place in 2021 .

\section{Analysis}

This paper aims to examine the development of student venture creation in a business model lab initiative with different types of actors involved. The analysis will highlight different 
IJEBR

27,5

types of tensions that arise. As discussed in the theoretical framework, Mele (2011) identifies five different types of tensions in network collaborations: task-related, process-related, rolerelated, affective and values-related. Further, the analysis will also discuss how tensions are handled and the consequences of these.

Types of student venture ideas

From the start, students were given information about the electric utility industry. The students were given brief information about some of the new developments taking place as well as the challenges ahead in the electric utility industry. Study visits to the utility companies were also arranged to provide more insights to the students. However, the complexity of the industry in terms of opportunities and constraints was difficult for the students to grasp. Early on, it became apparent that the students in Student Venture 1 were struggling to understand the aim and the goals of the business model lab. They also had difficulties understanding the content of the task. The students had been recruited but felt that they did not know what was expected of them or what the actual goal was of creating a student venture. There were discussions several times during board meetings about how to communicate goals and limitations to the student team. Some board members, that is, the companies, were unwilling to set up too many specifications and guidelines regarding the business model lab since too much direction could hamper or constrain students' creativity. The companies wanted the students to independently develop their own ideas and not be directed too much. However, the only direction the board gave was the goal of launching one product or service within one year. As Student Venture 1 started to develop, it became clear that the students were feeling lost. One student stated, "we are developing an idea that can help the electric utility companies retain customers since we can, of course, not start competing with the companies [involved in the business model lab].. Without further clarifications from the board, the students interpreted the goal as creating venture ideas to support the electric utility companies and that competing with them was out of the question. Eventually, the students of Student Venture 1 decided to develop an idea that could help utility companies attract and retain customers. The students did not want to compete with the established companies, so in coming up with creating different ideas, they finally landed on an idea based on gamification and building local communities. The idea was based on an app and would add value for the customers of electric utilities that would use the student venture's add-on service.

Nonetheless, the students kept working and presented their idea to the board. When the board was giving feedback, it became clear that even though it was said that there should not be any limitations or directions to hamper creativity, it was evident that the board had some specific ideas of what should come about, especially from the companies' side. For example, one business representative gave the following feedback to the students: "What I am considering is the technical barrier [for your idea], the meters here become essential... now many are changing their meters which increases the opportunities. But if we were to launch this today, you would face that not all would be able to use this... their technical conditions in their homes will not be compatible." This implies that the business representative wanted an idea that could be implemented for all his customers with the current technical status. Even though the overall project is focused on the future, it seemed to be a problem that not all customers would have the technical ability to use the service that the students presented.

At the next board meeting, the CEO of the business lab asked the board, "What are your expectations and interests? Is a community-based idea of interest to you. . . or something that is closer to your current business?" A business representative replied, "I have thought of it . . that we should not put out any limitations, everything that comes up is of interest and then see if we can get it to work if it is something that we believe in..., but maybe we need to put up some 
guidelines, I do not know." This indicates a strong belief that there should not be limitations, at least not at the start. However, the companies were starting to realize that guidelines and goals could be something that might have to be implemented to provide the students some direction.

The episode discussed is mainly based on task-related tension between the students and the companies. In line with Mele (2011), the task-related tension discussed is related to the differing opinions about the task itself, that is, what should be the focus of the student venture? Neither students nor business representatives had a clear picture of the content of the task at hand and what could be expected. The task was not specified, and when students presented their interpretation of the task, it became clear that the idea presented was not what the board had envisioned. In line with previous research, the episode discussed shows that tensions often occur between the participating actors when the expected outcome is not realized (Cunningham et al., 2018; Popa et al., 2020). The task-related tension between students and the companies also engaged the CEO of the business model lab. The students were frustrated and felt lost in what were the actual expectations from the board. The CEO of the business model lab felt the students' frustration and demanded the board to clarify their standpoints regarding the aim, goals and content of ideas. The CEO also asked for more specified guidelines. The students wanted to meet the expectations of the companies and the rest of the board, but the students did not understand what expectations there were. At the same time, the companies had a difficult time understanding why it was so important with aims, goals and expectations. Thus, affective-related tensions (Mele, 2011) are also visible in the episode discussed as an outcome of the task-related tensions. Students, companies and the CEO of the lab felt frustrated. Consequently, it was decided by the board that future new student venture teams would get more direction in what type of ideas would be suitable. When the second venture team started, it was clearly stated by the board that the focus was on selling electricity to students. One of the companies agreed to be a close partner with Student Venture 2 and provide most of the back office and production so that the second student team would focus on creating and designing a creative offering to students and concentrate on reaching the market by establishing a product offering. The degree of innovativeness was less of a concern. The business representatives of the board were actually very interested in venture ideas that would essentially compete directly with them.

\section{Expectations of students' ventures}

Expectations regarding the aim and goal of the student ventures were not explicitly discussed between all the participating actors (cf. Fyrberg Yngfalk, 2011), which early on raised questions among the students belonging to Student Venture 1 regarding how to conduct their work. A student stated, "What is a successful outcome? How do we measure it? How do we ensure that we reach it? This is something we tried to define and accomplish, but it was too vaguely worded. Purpose and goals must be concrete and be able to directly reflect the result. That is, a clear purpose should let us understand the project directive. A goal, if it is fulfilled, then the project also is successful." The students were recruited into the business model lab to create a student venture. However, the students were not clear what type of results were actually expected from the student ventures. Was it enough to come up with ideas? A student stated during a workshop, "We have gotten stuck a bit in. . . why do we exist? Or how should I put it?" The students were motivated by gaining new contacts in their network and wanted the companies to be satisfied with their work. However, as they did not exactly understand what was expected from them, they felt insecure and, at times, lost. The students had difficulties finding suitable ways of working to achieve predetermined goals, as the goals were not clearly formulated. The companies and also, to some extent, the researchers, had envisioned that the students would be self-driven and run the student 
IJEBR

27,5

1254

venture quite independently with some assistance from mentors and from the CEO that was assigned some limited hours to assist students. Accordingly, the students in Student Venture 1 had a great responsibility in asking for help from the CEO and mentors when deemed appropriate or necessary. The students were given the freedom and confidence to structure their own working process and timeline for when activities were supposed to happen, where help was offered when needed. The students in Student Venture 1 were assigned different areas of responsibility, such as market, product development and business development. Based on each student's area of responsibility, they were assigned a personal mentor representing one of the four companies. Each mentor had expert knowledge within their specific areas. The students in Student Venture 1 worked closely with the CEO but found it difficult to find flexible ways to interact and use mentors as a source of knowledge. Also, the mentors were unsure of their roles as mentors since each mentor was assigned a student with a specific responsibility. Some of the mentors interpreted this as being mentors for developing the individual student, while others tried to support the development of the student venture.

In this episode, tensions are related to both processes: how to do something to accomplish a task and roles, that is, who should do something and with which responsibility, as described by Mele (2011). The tension between students and business representatives came about from the students being unsure of how to work to succeed with their task. This is similar to the tensions that Meyer et al.'s (2011) find between industry expectations and students. However, our tension is more focused on the process, while Meyer's tensions seem to be more as an end result. Further, the different roles of the participating actors in the business model lab were not clearly explained. The students in Student Venture 1 did not understand the role of the mentors; for example, the mentors themselves did not understand their roles, either. As an effect, the students felt insecure and had a feeling of "us against them" when presenting and discussing their ideas with mentors as well as the board.

Based on the lessons learned, the common way of working between students in Student Venture 2, the CEO of the business model lab, mentors and the board were changed. The different roles were made clearer for all actors involved. The CEO and the students of Student Venture 2 jointly developed a timeline for when different activities were supposed to happen. The CEO arranged workshops with the students and mentors focusing on different venture creation activities, such as the development of an offering, a business model and a business plan. Weekly meetings between the students and the mentors were also arranged. The workshops and weekly meetings helped to clarify the roles of all actors. Thus, the mentors became a resource the students of Student Venture 2 could use for practical advice to move forward in the venture creation process. As one student explained, "It is good to discuss with mentors; it broadens the perspective and provides new input." These changes provided the student in Student Venture 2 with more structure than the first team of students.

\section{Ownership of student venture ideas}

One important question raised by the students in Student Venture 1 was connected to the ownership of the student ventures' ideas. The students asked, "Do we own the ideas that we develop?" The business model lab was incorporated so that the student ventures could conduct business for real. As the expectations were vague among the involved actors, it was unclear if the companies were interested in learning from the student ventures or if they were interested in the actual ventures, and this seemed to vary between the four companies. Once the business model lab was incorporated, the students were seen (from the companies perspective) as employees, and thus, an ambiguity was who would own the ideas that come out of the student ventures. The business partners argued that they invested some financing. Therefore, the corporations would own all ideas and that the students should be happy with 
the opportunities given to them. But the students did not have the exact same standpoint. One student stated, "Depending on where this project takes us, we just do not want to quit and give everything away." Another student said, "Even if I get a full-time job after this, I want to continue to work on this [implying not just leaving the ownership of the idea]."

Tension in this episode is connected to roles (Mele, 2011), where the students and the companies had different opinions regarding the roles of the students. The companies viewed the students as entrepreneurs working within a company, while the students initially had another view. This tension of ownership of the ideas is also clearly related to similar tensions that Meyer et al. (2011) find when collaborating between students and industry. This created tension, especially between the companies and the students. The students' motivation was to "make it big" and have great ideas. The issue of ownership affected the students' motivation initially, even though, in the end, they agreed that the incorporated business model lab would own the ideas. The business representatives assured the students that they would be such an important part of an idea that they would not just take a great idea without involving them further. That the students in Student Venture 2 were given more directions on the type of venture idea as well as pinpointing a lower degree of innovativeness reduced the tension of ownership of ideas since the actual uniqueness of the idea was not as prominent.

\section{Leadership and organization of student venture teams}

The idea of how the students in the student ventures should be organized was not something that the board of the business lab had thought about very much. It was taken for granted that the students would be motivated and able to organize themselves efficiently, just like regular startups figure out how to organize their work. However, it quickly became apparent that there is a difference between being recruited into a team and an organically formed team where a founder usually recruits people for specific roles. Thus, students applied to become a part of a student venture team and were interviewed by the CEO and the chairman of the board. None of the students knew each other before joining. The students had mixed backgrounds in terms of education, gender and experiences from entrepreneurial activities such as creating ventures. Thus, the teams were first formed, and then the teams were supposed to come up with venture ideas and act upon the ideas. In Student Venture 1, the students were recruited to different positions such as vice president, business manager, marketing manager and product development manager. The positions initially helped the students to organize themselves to a certain degree where the vice president took a more active role in structuring and organizing the internal work between students and also was responsible for convening meetings. However, the students quickly realized that as idea creation was central, everyone's input was important. The students, therefore, suggested skipping giving formal positions when recruiting students to Student Venture 2.

However, without formal positions in place, tensions related to roles, that is, who should do something and with what responsibility (Mele, 2011), arose between the students in Student Venture 2 (cf. Lundqvist et al., 2015). One student stated, "We students need to learn how we can work more efficiently and only do the work together that needs to be done together. There is a need for more structure in what needs to be done so that it can be divided up. The leadership has not been so strong..." The students found it difficult not only with the roles but also in dividing up the work and how the work should be conducted. Should all work be done together? What tasks could be done individually? Of course, the Covid-19 pandemic did not help this situation as most of the work was conducted digitally without many physical meetings. The consequence was that the work took longer than expected and that the time plans were not met. Some of the students in Student Venture 2 were frustrated and stressed with a feeling of not delivering as expected to the board. Also, some of the board members were annoyed and started to question the motivation, focus and time spent by the students. 
IJEBR

27,5

Accordingly, affective-related tensions (Mele, 2011) could be found between students and parts of the board.

\section{Resources available for student ventures}

Early on, the companies agreed to invest a smaller yearly amount in the business model lab that would cover the minimal running cost such as bookkeeping fees, small monetary compensation for the students and banking fees. There were discussions during early board meetings about if there was more capital available for the student ventures. The companies seemed to agree that the student ventures could pitch ideas and ask for additional investments from the companies.

Of course, it was important for the students to understand what types of resources were available. After receiving questions about this, the $\mathrm{CEO}$ of the business model lab asked for specifications during a board meeting. Again, the answer was that the students could ask for money and that the board would consider it. Following up on the question at a later board meeting with how this would work, it became clear that only the smaller investment for running fees was available for the students. The companies would not be able to quickly raise additional financial resources. One idea to overcome the issue of limited financial resources was to make more use of the TTO with its funding possibilities. The idea was discussed at a board meeting but dismissed by the companies. The researchers and the TTO were disappointed since they believed that the financial opportunities offered by the TTO would be helpful. The companies, in contrast, thought that too much time had been spent on discussing financing, structure and organization of the business model lab and the student ventures. The companies wanted to focus on getting some progress and interesting results from the student ventures. Thus, the limited financial resources available contributed to limiting the student venture ideas to simpler and less innovative ideas that would take less financial resources to develop. The student ventures, therefore, were forced to think more like a lean startup and develop ideas with minimum viable products.

In the episode discussed, tensions related to limited resources, in this case, financial resources, arose between the actors involved. Tensions related to limited resources are not addressed as part of the framework discussed by Mele (2011). Further, as an effect of the tension related to limited financial resources, affective-related tensions (Mele, 2011) grew between the researchers and the TTO contra the companies. Thus, we notice that affectiverelated tensions often result from previous underlying tensions of different types. The affective-related tensions often arose in situations where it was difficult for the parties to agree or when it took time to discuss and solve the underlying tension.

\section{Different institutional logics}

Previous research (Ambos et al., 2008; Steinmo, 2015) has shown that university and industry actors often have different time horizons, making university-industry collaborations challenging. Differing time horizons were also visible in the case discussed, and tensions arose within the collaboration. The students involved in the two student ventures had a short time horizon when joining the business model lab. The students have taken part for one or two terms and then ended their engagement either because they have graduated or since other things, such as their education, have been their number one priority. The companies, instead, have, during the development of the lab, pushed for things to happen more quickly and wanted to see progress and results early; however, they understood from the beginning that developing such collaboration takes time and that it will be a longer commitment that stretches over several years. Thus, the companies agreed to support the lab over a three-year period. The researchers are used to longer periods, where research projects often stretch over a minimum of three years. The output in publications from such a research project may add a 
few more years to the time horizon. Thus, this can be seen as an example of different institutional logics (cf. Steinmo, 2015) or value-related tensions (Mele, 2011), where companies are often driven toward short-term innovation outcomes, whereas researchers are primarily driven towards long-term outcomes such as international recognition and publications.

\section{Discussion}

In line with previous research on student venture creation, and as an answer to our research question, the analysis shows that several different types of tensions can appear during student venture creation (e.g. Hayter et al., 2017; Meyer et al., 2011). The five tensions identified in the analysis point to difficulties constructing student venture creation from a top-down perspective, with the main motivation coming from the supporting actors rather than from students themselves.

The tensions identified in this study point toward how the problems, conflicts and tensions that appear can be solved with an experiential learning and change approach. Even though there were several tensions, there has been engagement to change and develop the lab, although it takes time and effort from all parties to work through it. Conversely, had there not been a change, the collaboration would perhaps not have continued. Our findings are similar to Meyer et al. (2011) in that they also highlight how conflicting goals between the students' student venture creation in collaboration with industry can be a tough challenge and create tensions. Still, our research is not on a study program, rather a co-curricular activity.

Our research highlights the difficulty and complexity from a university perspective to create an environment for student venture creation in the context of university-industry collaboration, especially for a co-curricular activity. Research on the interaction between industry and education is very limited (Lackéus and Williams Middleton, 2015; Ollila and Williams-Middleton, 2011) and even less from the student venture creation based on co-curricular activities and interaction with industry perspective. The type of entrepreneurship that the students take part in is quite different compared to research conducted on other co-curricular student venture creation (see, e.g. Pittaway et al., 2015; Preedy et al., 2020; Preedy and Jones, 2017). The case we have studied is an activity that is not within a course or program, directing it more towards the co-curricular stream of research as the students are connected with the industry and provided with some basic directions (e.g. ideas should be within the electricity industry, and the second student venture got even more direction to sell electricity to students). This aspect of connection to the industry can also be seen in venture creation programs and courses, for example, Ollila and WilliamsMiddleton's (2011) research as well as Meyer et al. (2011). Naturally, courses and programs tend to have more structure and thought of progress compared to co-curricular activities. Therefore, it is not surprising that courses and programs have a more structured approach. Student venture creation from co-curricular activities is usually more student-driven, for example, the student clubs in Pittaway et al.'s (2015) research. Although our research is on a co-curricular activity, our research supports more the need for a structured approach (Lackéus and Williams Middleton, 2015; Meyer et al., 2011), whereas previous research on student venture creation outside of the classroom has argued for less structure and support on a need basis (Haneberg and Aaboen, 2020). Similarly, Wright et al. (2017) point out that building a support system helpful for student venture creation is not an easy task. Our research can, thus, contribute with a notion that these previous findings might not only be because of a curricular or co-curricular approach, but it might be the wider context, the type of ideas that students either create completely independently or are provided from collaboration with industry, how the teams are formed, and the expectations of the actors that are important factors for how to structure support. Thus, the specific context becomes important; 
IJEBR

27,5 it is not enough to pinpoint if the student venture creation takes place as a co-curricular activity or a curricular activity.

The structured way of venture creation within education also relates to team formation, where students are often put into a venture creation team and set up relationships with industry and TTOs (Lackéus and Williams Middleton, 2015; Lundqvist et al., 2015). Some programs also have an interdisciplinary approach, and Meyer et al. (2011) have found that it can be an important lesson for the students to comprehend diverse perspectives different from their own disciplines. This relates to the term surrogate entrepreneur, which refers to letting an experienced entrepreneur develop the business idea (Radosevich, 1995), which is also closely related to the type of entrepreneurship taking place in our case but still somewhat different. Incubators and TTOs have been found to sometimes use surrogate entrepreneurs with previous entrepreneurship experience and business knowledge to take charge and develop ideas, even though they might lack specific knowledge around the technology. Lundqvist (2014) studied ventures that had used surrogate entrepreneurs and found that these ventures performed significantly better on average. Our research shows a different type of surrogate entrepreneurship with students who do not have previous entrepreneurial experience and are not given a specific idea to further develop. Nonetheless, the companies are intrigued by the students' creativity, insight into new trends and ability to create ventures. This, what we can term as student surrogate entrepreneurship, has been used by several student venture creation courses and programs (Lackéus and Williams Middleton, 2015; Meyer et al., 2011; Ollila and Williams-Middleton, 2011), but we have not been able to find this approach with co-curricular student venture creation, which makes the current case unique. Our research points towards one important contextual factor: if the student surrogate entrepreneurship approach is applied, it has consequences for how support and structure should be organized.

With regard to the actors, in this case, all saw opportunities to be part of the business model lab. However, being embedded in a network does not necessarily lead to value creation, only the opportunities to do so, where the tension between the collaborating parties often hampers value creation in the short run (cf. Hasche and Linton, 2018), which is illustrated within the case analyzed. The opportunity of being embedded in a network consisting of actors from both academia and industry provided the students with opportunities for easy access to a variety of different resources that often are vital for survival in the initial phase of establishing a new venture. In specific relation to student ventures, Haneberg and Aaboen (2020) discuss the importance of the right competence in new ventures. Having students connected very closely with experts in the industry was thought to provide quick and excellent results in the case investigated in this study. Nonetheless, this factor did not enable immediate success like other aspects, such as the team formation, specific industry collaboration and a top-down approach, which also affected the business model lab and the student venture creation in other ways. This ties well together with the findings of Meyer et al. (2011), who argue that well-designed programs for students in combination with skillful practitioners as mentors can lead to invaluable insights. Nonetheless, this case shows the complexity of facilitating student venture creation in the wider context of universityindustry collaborations (Cunningham et al., 2018; Hasche et al., 2020) and for universities to become more entrepreneurial (Etzkowitz et al., 2000; Heinonen and Hytti, 2010). Previous research has also pointed towards how collaborations can fail because actors have different interests and goals with the collaboration and that negative narratives around the entrepreneurial university have been toned down (Jensen and Tragardh, 2004).

\section{Conclusions}

Our paper contributes with research based on a case study that shows a different type of student venture creation compared to earlier student venture creation research, such as 
student venture creation courses and programs and co-curricular student venture creation. Our research points toward the importance of the specific situation and context, emphasizing what type of support and structure should surround the student venture creation, rather than classifying it as co-curricular and curricular student venture creation. Our findings also point to the inherent difficulties in managing and organizing student venture creation. The previous literature on student venture creation points to the advantages of networks, which create many opportunities. The case in our paper illustrates that networks surrounding the student venture creation process can also lead to several different types of tensions. These tensions need to find suitable solutions, and the actors need to learn from their mistakes and reconfigure the network to overcome shortages (Hayter et al., 2017), a learning perspective that can be useful for improvement. Our discussion about student surrogate entrepreneurship can hopefully spark further research interest within student venture creation research. Building on this, we also invite future research to investigate student venture creation and identify other important contextual factors that can impact student venture creation, such as industry collaboration, where the idea for the venture comes from team formation.

Practical implications can be derived from the current research. For example, for university and industry collaboration to function in a good way, highly skilled mentors must be engaged and continually support the student ventures. Another important implication that our research supports is the importance of a collaborative learning perspective from the network and business lab actors. Focusing on how every actor can learn through the business model lab rather than wealth creation can help actors set expectations and obtain reasonable results (Meyer et al., 2011). Another practical implication is that although the business model lab had its fair share of tensions, through a collaborative approach from the different actors, solutions were found, and improvements to the business model lab were made. The final practical contribution is to focus on the learning achieved during student venture creation rather than creating great ventures. Even if the ventures fail, companies, researchers, and students can still get valuable insights.

The empirical part of this paper is based on a single-case study. While it captures multiple collaborations, the empirical scope of the study is limited. Hence, further case studies are needed to explore student venture creation and what it means to be embedded in networks in further depth. Our case is located in a unique situation and context, which makes generalizations difficult. Given this, it would be beneficial to carry out studies in other contexts to explore the transferability of our findings. The lack of studies on tension in networks and the consequences of these tensions for further development of relationships and networks make ground for future interesting and valuable studies in other contexts.

\section{References}

Aadland, T. and Aaboen, L. (2020), "An entrepreneurship education taxonomy based on authenticity", European Journal of Engineering Education, Vol. 45 No. 5, pp. 711-728.

Abreu, M., Demirel, P., Grinevich, V. and Karataş-Özkan, M. (2016), "Entrepreneurial practices in research-intensive and teaching-led universities", Small Business Economics, Vol. 47 No. 3, pp. 695-717.

Alderson, W. (1957), Marketing Behavior and Executive Action: A Functionalist Approach to Marketing Theory, Irwin, Homewood, Ill.

Ambos, T.C., Mäkelä, K., Birkinshaw, J. and D'Este, P. (2008), "When does university research get commercialized? Creating Ambidexterity in research institutions", Journal of Management Studies, Vol. 45 No. 8, pp. 1424-1447.

Bagozzi, R.P. (1975a), "Social exchange in marketing”, Journal of the Academy of Marketing Science, Vol. 3 Nos 3-4, pp. 314-327. 
IJEBR

27,5

Bagozzi, R.P. (1975b), “Marketing as exchange”, Journal of Marketing, Vol. 39 No. 4, pp. 32-39.

Barba-Sánchez, V. and Atienza-Sahuquillo, C. (2018), "Entrepreneurial intention among engineering students: the role of entrepreneurship education", European Research on Management and Business Economics, Vol. 24 No. 1, pp. 53-61.

Bergmann, H., Hundt, C. and Sternberg, R. (2016), "What makes student entrepreneurs? On the relevance (and irrelevance) of the university and the regional context for student start-ups", Small Business Economics, Springer, Vol. 47 No. 1, pp. 53-76.

Boh, W.F., De-Haan, U. and Strom, R. (2016), "University technology transfer through entrepreneurship: faculty and students in spinoffs", The Journal of Technology Transfer, Vol. 41 No. 4, pp. 661-669.

Corsaro, D. and Snehota, I. (2011), "Alignment and misalignment in business relationships", Industrial Marketing Management, Vol. 40 No. 6, pp. 1042-1054.

Cunningham, J.A., Menter, M. and O'Kane, C. (2018), "Value creation in the quadruple helix: a micro level conceptual model of principal investigators as value creators", R\&D Management, Vol. 48 No. 1, pp. 136-147.

Dubois, A. and Gadde, L.E. (2002), "Systematic combining: an abductive approach to case research", Journal of Business Research, Vol. 55 No. 7, pp. 553-560.

Dubois, A. and Gadde, L.E. (2014), “'Systematic combining'-a decade later”, Journal of Business Research, Vol. 67 No. 6, pp. 1277-1284.

Eisenhardt, K.M. (1989), "Making fast strategic decisions in high-velocity environments", The Academy of Management Journal, Vol. 32 No. 3, pp. 543-576.

Eisenhardt, K.M. (1991), "Better stories and better constructs: the case for rigor and comparative logic", Academy of Management Review, Vol. 16 No. 3, pp. 620-627.

Eisenhardt, K.M. and Graebner, M.E. (2007), "Theory building from cases: opportunities and challenges", Academy of Management Journal, Vol. 50 No. 1, pp. 25-32.

Etzkowitz, H. and Leydesdorff, L. (2000), "The dynamics of innovation: from national systems and 'Mode 2' to a Triple Helix of university-industry-government relations", Research Policy, Vol. 29 No. 2, pp. 109-123.

Etzkowitz, H., Webster, A., Gebhardt, C. and Terra, B.R.C. (2000), "The future of the university and the university of the future: evolution of ivory tower to entrepreneurial paradigm", Research Policy, Vol. 29 No. 2, pp. 313-330.

Fang, S.-R., Chang, Y.-S. and Peng, Y.-C. (2011), "Dark side of relationships: a tensions-based view", Industrial Marketing Management, Vol. 40 No. 5, pp. 774-784.

Fyrberg Yngfalk, A. (2011), Co-Creating Value: Reframing Interactions in Service Consumption, School of Business, Stockholm University, Stockholm.

Goel, R.K., Göktepe-Hultén, D. and Ram, R. (2015), “Academics’ entrepreneurship propensities and gender differences”, The Journal of Technology Transfer, Vol. 40 No. 1, pp. 161-177.

Goldfarb, B. and Henrekson, M. (2003), "Bottom-up versus top-down policies towards the commercialization of university intellectual property", Research Policy, Vol. 32 No. 4, pp. 639-658.

Gulati, R., Nohria, N. and Zaheer, A. (2000), "Strategic networks", Strategic Management Journal, Vol. 21 No. 3, pp. 203-215.

Haneberg, D.H. and Aaboen, L. (2020), "Incubation of technology-based student ventures: the importance of networking and team recruitment", Technology in Society, Vol. 63, p. 101402 .

Hasche, N. and Linton, G. (2018), "The value of failed relationships for the development of a Medtech start-up", Journal of Small Business and Entrepreneurship, Vol. 30 No. 1, pp. 97-119. 
Hasche, N., Höglund, L. and Linton, G. (2020), "Quadruple helix as a network of relationships: creating value within a Swedish regional innovation system", Journal of Small Business and Entrepreneurship, Vol. 32 No. 6, pp. 523-544.

Hayter, C.S., Lubynsky, R. and Maroulis, S. (2017), "Who is the academic entrepreneur? The role of graduate students in the development of university spinoffs", The Journal of Technology Transfer, Vol. 42 No. 6, pp. 1237-1254.

Heinonen, J. and Hytti, U. (2010), "Back to basics: the role of teaching in developing the entrepreneurial university", The International Journal of Entrepreneurship and Innovation, Vol. 11 No. 4, pp. 283-292.

Herman, E. and Stefanescu, D. (2017), "Can higher education stimulate entrepreneurial intentions among engineering and business students?”, Educational Studies, Vol. 43 No. 3, pp. 312-327.

Hughes, M., Ireland, R.D. and Morgan, R.E. (2007), "Stimulating dynamic value: social capital and business incubation as a pathway to competitive success", Long Range Planning, Vol. 40 No. 2, pp. 154-177.

Huyghe, A., Knockaert, M. and Obschonka, M. (2016), 'Unraveling the 'passion orchestra' in academia”, Journal of Business Venturing, Vol. 31 No. 3, pp. 344-364.

Jain, S., George, G. and Maltarich, M. (2009), “Academics or entrepreneurs? Investigating role identity modification of university scientists involved in commercialization activity", Research Policy, Vol. 38 No. 6, pp. 922-935.

Jensen, C. and Tragardh, B. (2004), "Narrating the Triple Helix concept in 'weak' regions: lessons from Sweden”, International Journal of Technology Management, Vol. 27 No. 5, pp. 513-530.

Johnstone, B.A. (2007), "Ethnographic methods in entrepreneurship research", Handbook of Qualitative Research Methods in Entrepreneurship, Edward Elgar Northampton, Massachusetts, MA, pp. 97-121.

Jorgensen, D.L. (2015), "Participant observation", Emerging Trends in the Social and Behavioral Sciences, American Cancer Society, pp. 1-15.

Karlsson, T. and Wigren, C. (2012), "Start-ups among university employees: the influence of legitimacy, human capital and social capital", The Journal of Technology Transfer, Vol. 37 No. 3, pp. 297-312.

Kask, J. and Linton, G. (2013), "Business mating: when start-ups get it right”, Journal of Small Business and Entrepreneurship, Vol. 26 No. 5, pp. 511-536.

Klofsten, M., Fayolle, A., Guerrero, M., Mian, S., Urbano, D. and Wright, M. (2019), "The entrepreneurial university as driver for economic growth and social change - key strategic challenges", Technological Forecasting and Social Change, Vol. 141, pp. 149-158.

Kolb, C. and Wagner, M. (2015), "Crowding in or crowding out: the link between academic entrepreneurship and entrepreneurial traits", The Journal of Technology Transfer, Vol. 40 No. 3, pp. 387-408.

Lackéus, M. and Williams Middleton, K. (2015), "Venture creation programs: bridging entrepreneurship education and technology transfer", Education + Training, Vol. 57 No. 1, pp. $48-73$.

Landström, H. and Harirchi, G. (2019), “That's interesting! in entrepreneurship research”, Journal of Small Business Management, Vol. 57 No. S2, pp. 507-529.

Landström, H., Harirchi, G. and Åström, F. (2012), "Entrepreneurship: exploring the knowledge base”, Research Policy, Vol. 41 No. 7, pp. 1154-1181.

Liñán, F., Ceresia, F. and Bernal, A. (2018), "Who intends to enroll in entrepreneurship education? Entrepreneurial self-identity as a precursor”, Entrepreneurship Education and Pedagogy, Vol. 1 No. 3, pp. 222-242.

Linton, G. and Klinton, M. (2019), "University entrepreneurship education: a design thinking approach to learning", Journal of Innovation and Entrepreneurship, Vol. 8 No. 1, p. 3. 
IJEBR

27,5
Lundqvist, M.A. (2014), "The importance of surrogate entrepreneurship for incubated Swedish technology ventures", Technovation, Vol. 34 No. 2, pp. 93-100.

Lundqvist, M., Middleton, K.W. and Nowell, P. (2015), "Entrepreneurial identity and role expectations in Nascent entrepreneurship", Industry and Higher Education, Vol. 29 No. 5, pp. 327-344.

Marion, T.J., Eddleston, K.A., Friar, J.H. and Deeds, D. (2015), "The evolution of interorganizational relationships in emerging ventures: an ethnographic study within the new product development process", Journal of Business Venturing, Vol. 30 No. 1, pp. 167-184.

Markman, G.D., Phan, P.H., Balkin, D.B. and Gianiodis, P.T. (2005), "Entrepreneurship and universitybased technology transfer", Journal of Business Venturing, Vol. 20 No. 2, pp. 241-263.

Mele, C. (2011), "Conflicts and value co-creation in project networks", Industrial Marketing Management, Vol. 40 No. 8, pp. 1377-1385.

Meyer, A.D., Aten, K., Krause, A.J., Metzger, M.L. and Holloway, S.S. (2011), “Creating a university technology commercialisation programme: confronting conflicts between learning, discovery and commercialisation goals", International Journal of Entrepreneurship and Innovation Management, Vol. 13 No. 2, pp. 179-198.

Miles, M.B. and Huberman, A.M. (1994), Qualitative Data Analysis: An Expanded Sourcebook, Sage, Thousand Oaks, California, CA.

Miranda, F.J., Chamorro-Mera, A. and Rubio, S. (2017), "Academic entrepreneurship in Spanish universities: an analysis of the determinants of entrepreneurial intention", European Research on Management and Business Economics, Vol. 23 No. 2, pp. 113-122.

Musante, K.M. and DeWalt, B.R. (2010), Participant Observation: A Guide for Fieldworkers, Altamira, Lanham, Maryland.

Nabi, G., Walmsley, A., Liñán, F., Akhtar, I. and Neame, C. (2018), "Does entrepreneurship education in the first year of higher education develop entrepreneurial intentions? The role of learning and inspiration”, Studies in Higher Education, Vol. 43 No. 3, pp. $452-467$.

Nosella, A. and Petroni, G. (2007), "Multiple network leadership as a strategic Asset: the carlo Gavazzi space case", Long Range Planning, Vol. 40 No. 2, pp. 178-201.

Öberg, C. and Shih, T.T.Y. (2014), "Divergent and convergent logic of firms: barriers and enablers for development and commercialization of innovations", Industrial Marketing Management, Vol. 43 No. 3, pp. 419-428.

Öberg, C., Dahlin, P. and Pesämaa, O. (2020), “Tension in networks”, Industrial Marketing Management, Vol. 91, pp. 311-322.

Ollila, S. and Williams-Middleton, K. (2011), "The venture creation approach: integrating entrepreneurial education and incubation at the university", International Journal of Entrepreneurship and Innovation Management, Vol. 13 No. 2, pp. 161-178.

Philpott, K., Dooley, L., O’Reilly, C. and Lupton, G. (2011), "The entrepreneurial university: examining the underlying academic tensions", Technovation, Vol. 31 No. 4, pp. 161-170.

Pittaway, L.A., Gazzard, J., Shore, A. and Williamson, T. (2015), "Student clubs: experiences in entrepreneurial learning", Entrepreneurship and Regional Development, Vol. 27 Nos 3-4, pp. 127-153.

Popa, E.O., Blok, V. and Wesselink, R. (2020), "A processual approach to friction in quadruple helix collaborations”, Science and Public Policy, Vol. 47 No. 6, pp. 876-889.

Power, J., Sinnott, E., O'Gorman, B. and Fuller-Love, N. (2014), "Eveloping self-facilitating learning networks for entrepreneurs: a guide to action”, International Journal of Entrepreneurship and Small Business, Vol. 21 No. 3, pp. 334-354.

Preedy, S. and Jones, P. (2017), "Student-led enterprise groups and entrepreneurial learning: a UK perspective", Industry and Higher Education, Vol. 31 No. 2, pp. 101-112.

Preedy, S., Jones, P., Maas, G. and Duckett, H. (2020), "Examining the perceived value of extracurricular enterprise activities in relation to entrepreneurial learning processes", Journal of Small Business and Enterprise Development, Vol. 27 No. 7, pp. 1085-1105. 
Radosevich, R. (1995), "A model for entrepreneurial spin-offs from public technology sources", International Journal of Technology Management, Vol. 10 Nos 7-8, pp. 879-893.

Rasmussen, E.A. and Sørheim, R. (2006), “Action-based entrepreneurship education”, Technovation, Vol. 26 No. 2, pp. 185-194.

Robinson, S., Neergaard, H., Tanggaard, L. and Krueger, N.F. (2016), "New horizons in entrepreneurship education: from teacher-led to student-centered learning", Education + Training, Vol. 58 Nos 7/8, pp. 661-683.

Shirokova, G., Osiyevskyy, O., Morris, M.H. and Bogatyreva, K. (2017), "Expertise, university infrastructure and approaches to new venture creation: assessing students who start businesses", Entrepreneurship and Regional Development, Routledge, Vol. 29 Nos 9-10, pp. 912-944.

Siggelkow, N. (2007), "Persuasion with case studies", Academy of Management Journal, Vol. 50 No. 1, pp. 20-24.

Steinmo, M. (2015), "Collaboration for innovation: a case study on how social capital mitigates collaborative challenges in university-industry research Alliances", Industry and Innovation, Vol. 22 No. 7, pp. 597-624.

Street, C.T. and Cameron, A.F. (2007), "External relationships and the small business: a review of small business Alliance and network research*", Journal of Small Business Management, Vol. 45 No. 2, pp. 239-266.

Thom, M. (2017), "Arts entrepreneurship education in the UK and Germany: an empirical survey among lecturers in fine art", Education + Training, Vol. 59 No. 4, pp. 406-426.

Walter, A., Auer, M. and Ritter, T. (2006), "The impact of network capabilities and entrepreneurial orientation on university spin-off performance", Journal of Business Venturing, Vol. 21, pp. 541-567.

Wright, M., Siegel, D.S. and Mustar, P. (2017), “An emerging ecosystem for student start-ups”, The Journal of Technology Transfer, Vol. 42 No. 4, pp. 909-922.

\section{Corresponding author}

Gabriel Linton can be contacted at: gabriel.linton@oru.se

For instructions on how to order reprints of this article, please visit our website:

www.emeraldgrouppublishing.com/licensing/reprints.htm

Or contact us for further details: permissions@emeraldinsight.com 